\title{
STAGES OF THE ARTISTIC REALIA INTRODUCTION INTO ENGLISH LITERARY TEXTS
}

\author{
Chernyk Maryna \\ Candidate of Sciences in Philology \\ ORCID ID 0000-0002-3666-0671 \\ Sumy State University \\ 2, Rymskoho-Korsakova St, Sumy, 40007, Ukraine \\ m.chernik@gf.sumdu.edu.ua
}

The article is devoted to the differentiation of the stages of the artistic realia introduction into English literary texts based on the artistic communicative situations, taking into account the peculiarities of the communicants' interaction, artworks actualisation, and realisation of time and space characteristics in the artistic discourse. The stage by stage differentiation of the artworks introduction into the literary text is developed based on the structural analysis of the artistic communicative situations. Accordingly, there are preintroductive, introductive, and postintroductive stages. The completeness of each stage representation is determined by the form of the artwork in the literary text and can be complete, compressed, or zero.

In the article, the peculiarities of each stage are defined based on the analysis of the illustrative material. There are preintroductive (determining the time and space parameters of the communicative situation before artwork mentioning, introduction of the participants and description of their appearance and inner state), introductive (introduction of the artwork into the communicative situation, description of such components as form, meaning, artwork characteristics, and emotions connected with it), and postintroductive stages (reaction to the artwork after its perception, realised in the form of the verbalised or non-verbalised communication and capable of stimulating the discussion of the perceived information).

Special attention is given to the peculiarities of the artworks introduction from the performer's and the recipient's points of view; the details and aspects of their descriptions are considered. Depending on the person who tells the story, the stages of introduction can be prerepresentational, representational, and postrepresentational (in the performer's descriptions) or preperceptive, perceptive, and postperceptive (in the recipient's descriptions).

Keywords: communicative situation, artistic realia, artwork, performer, recipient.

\section{ЕТАПИ ІНТРОДУКЦЇ̈ МИСТЕЦЬКИХ РЕАЛІЙ В АНГЛОМОВНІ ХУДОЖНІ ТЕКСТИ}

Черник Марина

Кандидат філологічних наук, ORCID ID 0000-0002-3666-0671

Сумський державний університет вул. Римського-Корсакова, 2, м. Суми, 40007, Україна m.chernik@gf.sumdu.edu.ua

(C) Chernyk M., 2020 
Стаття присвячена диференціації етапів інтродукиї мистещььких реалій в англомовні художні тексти, які інтегруються в мистецькі комунікативні ситуації, з урахуванням особливостей інтеракиії комунікантів, актуалізації твору мистецттва та реалізаиї часо-просторових характеристик у мистецькому дискурсі. На основі аналізу структури мистецької комунікативної ситуації розроблено поетапну диференціацію введення творів мистецтвва в художній текст, згідно з якою виокремлені передінтродуктивний, інтродуктивний $i$ постінтродуктивний етапи. Повнота репрезентації кожного етапу визначається формою актуалізації твору мистецтвв в художньому тексті й може бути повною, згорнутою або нульовою.

У статті на основі аналізу ілюстративного матеріалу виявляються закономірності реалізачії кожного з етапів: передінтродуктивного (визначення часо-просторових параметрів комунікативної ситуації перед появою твору мистецтвв, введення учасників спілкування $i$ опис їх зовнішності й внутрішнього стану), інтродуктивного (безпосереднє введення твору мистецтвва в комунікативну ситуацію, опис таких складових, як форма, значення, характеристика твору мистецттва, а також формування емочій та вражень від нього) та постінтродуктивного (реакція на твір мистецтвва після його сприйняття, яка реалізується на рівні вербалізованої та невербалізованої реакції й має потенціал давати поштовх для початку обговорення сприйнятої інформачії).

Особлива увага приділясться відмінностям інтродукиіі творів мистецтва з позицій репрезентатора та рециипієнта, розглядаються деталі й аспекти, які актуалізуються в їх описах. Залежно від особи, яка веде розповідь, етапи інтродукиії поділяються на передрепрезентачійний, репрезентаиійний, пострепрезентачійний (в описах репрезентатора) або передпериептивний, периептивний та постперцептивний (в описах реципієнта).

Ключові слова: комунікативна ситуачія, мистецька реалія, твір мистецтва, репрезентатор, рециипієнт.

Introduction. An artistic phenomenon as an integral part of the interpersonal and intercultural communication has a broad potential to be represented in the literary texts. The communicative and discursive aspects of using the artistic realia involve the study of the participants' communication, artworks actualisation, and time and space characteristics in the artistic discourse. An analysis of the peculiarities of the artworks' stage-by-stage introduction into the communicative situation allows understanding the ways of the authors' intentions achieving, connected with artworks descriptions, and making up the relevance of the study.

The purpose of the article is to study the peculiarities of different stages of the artistic realia introduction (the specific topic) into the artistic communicative situations described in the English literary texts (the subject area).

This purpose implies the following tasks of the research: to identify the role of the artistic phenomenon in the literary discourse; to differentiate the stages of the artistic realia introduction into the communicative situations; to reveal the peculiarities of each stage; to consider the difference between the performer's and the recipient's perception of the stages of the artistic communicative situations.

The theoretical basis of the study is provided by the works in the field of the discourse theory (V. I. Karasyk, T. F. Plekhanova [3; 5]), communicative linguistics (F. S. Batsevych, I. A. Bekhta [1; 2]), intercultural communication (V. M. Manakin, I. M. Rudyk [4; 7]), nonverbal communication (L. V. Soloshchuk, V. S. Kulish $[8 ; 12]$ ), and linguistic aspects of the artistic phenomenon actualisation (T. V. Surodeikina, C. R. Hausman, D. Ludden, G. Rippl $[9 ; 11 ; 13 ; 14]$.

Results of the research. The form of the artistic realia actualised in English literary text determines the stages of their introduction. The compressed and zero forms foresee only some nomination and short description, e. g., His masterful composition Rosaline has been a worldwide sensation and has made Britain proud [17, p. 279]. The complete form of the 
artistic realia introduction into the literary text foresees a full-range description of the stages of the artworks performance in the artistic communicative situation, which are determined by such artistic discourse factors as communicants, time and space characteristics, type, and role of the artwork. These factors influence the order and peculiarities of the artistic realia introduction into the literary texts. Despite the diversity of the possible ways how the artistic communicative situations can be developed, there are universal criteria of their structure segmentation into such stages: preintroductive, introductive, and postintroductive. Depending on the author's intention, the attention can be focused only on one of the stages, and other stages are represented in a short form or they are not described at all.

The initial stage of the artistic communicative situation is the preintroductive stage, preceding the artwork introduction. At this stage, the time and space parameters of the communicative situation are determined, the communicants are introduced; their appearance and internal state expressed through their thoughts, emotions, and feelings are characterised. All these components constitute precondition and ground for the artworks introduction into the communicative process.

An artwork introduction foresees a previous description of the recipient's perception of the artist, which can be expressed verbally and non-verbally, e. g., There's a sudden hush when they see me. And then a rolling buzz and claps of welcome. Then all at once, everybody's talking at me. It's the Mozart Man they see today, not the Prime Minister [17, p. 264].

The combined description of the artist's and audience's actions at the preintroductive stage provides a general atmosphere of the communicative situation, e. g., Through the vacuum with an easy step, Richard Hall makes his way to take his place. A subtle smile and a slight bow and the world around him erupts into sound. Five hundred men and women rise together within the thunder of their welcome, and she must lead that applause [17, p. 272]. The artist's actions provide us with the implicit characteristics of his internal state (easy step, subtle smile) and are supplemented by the conventional non-verbal motion of a bow, which is typical for such communicative situations (slight bow). The audience's actions are also marked by conventionality and are verbalised by such words as rise together, welcome, applause.

In case the story is told by the performer, the attention is focused on the internal state of the artist and his perception of the surrounding, e. g., My mind races: Leila, work, Ana... and I know I won't get back to sleep. Getting up, I pull on some PJ pants, close the bedroom door, and head into the living room to my piano [21, p. 354].

In the following example, the attention is focused on the preintroductive stage of the artistic communicative situation: Suddenly I felt very lonely. It had started to snow. Fairytale-like snowflakes fell slowly and softly. Winter settled on Harvard and me. Powdery flakes brushed against my face and melted as they met tears I didn't even know were there. But darkness never comes to Harvard Square. Here, winter keeps her distance. It's the place to go to lift one's soul. To find refuge. Low clouds reflected the square's golden glow, and the sky seemed near-near enough to reach out and touch. It was like day, so many lights, so much noise. There were jugglers and street musicians, vendors and shoppers. People. People everywhere doing everything and nothing. That fellow over there. Sounds of Dylan floated around him, rhythmic and brilliant. Pure poetry touched my heart. Music and words flowed at me, blowing in the wind [17, p. 91]. The author gives a detailed description of the recipient's psychological state (I felt very lonely; they met tears I didn't even know were there), time (It had started to snow; Winter settled on Harvard; It was like day), space (It's the place to go to lift one's soul. To find refuge; square's golden glow; so many lights, so much noise), and participants of the communicative situation (There were jugglers and street musicians, vendors and shoppers. People. People everywhere doing everything and nothing). After that, he introduces the performer's image (That fellow over there), actualises the performance of the music artwork (Sounds of Dylan floated around 
him, rhythmic and brilliant), and describes its perception by the recipient (Pure poetry touched my heart).

The next stage of the artistic communicative situation is the introductive stage, where the artwork occurs in the communication. The process of its introduction foresees the description of such components as form, meaning, and characteristics of the artwork. Also, the emotions and impressions are formed at this stage; they are verbalised in the communicants' thoughts or expressed through the descriptions of the components of nonverbal communication.

Music artworks can introduce the sound beginning and foresee verbalisation of such components of artwork nomination as author, title, genre, and means of representation, e. g., José Gonzalez starts to sing a soothing melody with a hypnotic guitar riff [18, p. 36].

Let us analyse the peculiarities of the music introducing from the performer's and the recipient's points of view, considering the novels by E. L. James Fifty Shades of Grey and Grey, where identical events are described by different characters (table 1):

Table 1. The comparison of the recipient's and performer's artwork introduction into literary text

\begin{tabular}{|c|c|c|}
\hline Stage & Recipient & Performer \\
\hline 1 & $\begin{array}{l}\text { "Play the other one." "Other one?" } \\
\text { "The Bach piece that you played the } \\
\text { first night I stayed." "Oh, the } \\
\text { Marcello." }\end{array}$ & $\begin{array}{l}\text { "Play the other one." "Other } \\
\text { one?" "The Bach piece that you } \\
\text { played the first night I stayed." } \\
\text { "Oh, the Marcello." } \\
\text { I can't remember when I last } \\
\text { played for someone upon request. } \\
\text { For me the piano is a solitary } \\
\text { instrument, for my ears only. My } \\
\text { family hasn't heard me play for } \\
\text { years. But since she's asked, I'll } \\
\text { play for my sweet Ana. }\end{array}$ \\
\hline 2 & $\begin{array}{l}\text { He starts to play slowly and } \\
\text { deliberately. I feel the movement of his } \\
\text { hands in his shoulder as I lean against him } \\
\text { and close my eyes. The sad, soulful notes } \\
\text { swirl slowly and mournfully around us, } \\
\text { echoing off the walls. It is a hauntingly } \\
\text { beautiful piece, sadder even than the } \\
\text { Chopin, and I lose myself to the beauty of } \\
\text { the lament. To a certain extent, it reflects } \\
\text { how I feel. The deep poignant longing I } \\
\text { have to know this extraordinary man better, } \\
\text { to try and understand his sadness. All too } \\
\text { soon, the piece is at an end. }\end{array}$ & $\begin{array}{l}\text { My fingers caress the keys and } \\
\text { the haunting melody echoes through } \\
\text { the living room. }\end{array}$ \\
\hline 3 & $\begin{array}{l}\text { "Why do you only play such sad } \\
\text { music?" [20, p. 345] }\end{array}$ & $\begin{array}{l}\text { "Why do you only play such sad } \\
\text { music?" she asks [21, p. 355] }\end{array}$ \\
\hline
\end{tabular}

The preintroductive (1) and postintroductive (3) stages are realised in both novels similarly, except for the preintroductive stage in the performer's conscience is complemented by his speculations, which are the reaction to the recipient's request to perform the music artwork (I can't remember when I last played for someone upon request). Considerable differences are observed at the introductive stage (2). The recipient's description of the music artwork is much more extensive than the performer's one. In both examples, the performer's actions are given first: He starts to play slowly and deliberately. I feel the movement of his hands in his shoulder as I lean against him and close my eyes (recipient's description); My fingers caress the keys (performer's description). After that, the author introduces the artwork itself. The performer's description of the artwork is short (the haunting melody), and it determines the location of the communicative situation 
(echoes through the living room). The recipient's description is more extensive, and it is realised by such nominations as soulful notes swirl slowly and mournfully around us, sadder even than the Chopin, beauty of the lament. The recipient provides us with the varied description of the music artwork compared to the performer's description based on the lexeme haunt (hauntingly beautiful piece). The location of the communicative situation in the recipient's description is less detailed and is expressed by means of the phrase echoing off the walls. After describing the artwork, the recipient begins thinking of the way the music and its mood correlate (To a certain extent, it reflects how I feel); and then the music causes new intentions in the recipient (I have to know this extraordinary man better, to try and understand his sadness). The music ending is actualised only in the recipient's description (All too soon, the piece is at an end).

The visual artworks are introduced into the communicative situation through the description of the finished picture or the process of its creation.

In case the finished picture is described, the attention is focused on its subject, technique, parameters, and recipient's emotions, e. g., And there in the dark of the landing - Raymond caught his breath, heart pounding - was Galena's ravishing drawing of a naked Rupert asleep in the crimson-curtained four-poster in the Blue Tower [15, p. 175]. It is reasonable to mention that in this example, the reaction to the picture (Raymond caught his breath, heart pounding) precedes the introduction of the artwork itself.

Creating pictures in the literary texts foresees descriptions of both picture creation dynamics, and external and psychological characteristics of the artist, e. g., When the window was thoroughly steamed, Malcolm used it as a canvas. "I know you can't waste your energy drawing. So I will," he said as he drew a girl flying-not floating but flyinggliding over a small world beneath her. He worked slowly and carefully, and I watched every stroke. I could see slivers of his reflection in the window where he was drawing. The soles of the girl's feet were in the foreground. Her arms stretched in front of her like a superhero. Her right pointer finger reaching forward ... almost touching another hand-his hand. A boy stretched out in the far distance, connected to the earth but reaching up and up, attempting the incredible feat of touching her finger. Nearly grasping her. It was kind of like The Creation of Adam in the Sistine Chapel, where God reaches to Adam and Adam reaches to God, their fingertips nearly touching. That was me and Malcolm: so close to each other yet impossibly apart. Impossibly disconnected [22, p. 106].

In the following example, the author avoids the picture description, focusing his attention only on the actions of the artist and ideas embodied in his works: Dad doesn't seem to see the backyard or the chickens when he's painting, though. It's not just the snapshot or the canvas he sees either. It's something much bigger. He gets this look in his eye like he's transcended the yard, the neighborhood, the world. And as his big, callused hands sweep a tiny brush against the canvas, it's almost like his body has been possessed by some graceful spiritual being [16, p. 23]. At that, the author stresses that the artist is abstracted from the reality (Dad doesn't seem to see the backyard or the chickens when he's painting).

Usually, at the introductive stage, the performer is focused on the artwork. Though there are cases, when the interaction between the communicants also occurs during the performance and is expressed through non-verbal actions of the participants in the communicative situation, e. g., He doesn't look up as I near the piano, but shifts to one side so I can sit beside him on the piano bench. He continues to play, and I put my head on his shoulder. He kisses my hair but doesn't stop playing until he's finished the piece [19, p. 254]. Non-verbal actions of the recipient can be expressed using the description of approaching (I near the piano, sit beside) and touching (I put my head on his shoulder). The performer answers by kissing the recipient's hair without delaying in playing (He kisses my hair).

The final stage of the artistic communicative situation is the postintroductive stage, which occurs after the end of the artwork introduction. This stage provides us with the artwork impression, realised at the level of the verbalised and non-verbalised reaction; the 
artwork stimulates the discussion of the perceived information. Usually, the artwork perception is followed by the non-verbal reaction, which is verbalised later.

The reaction to the artwork depends on the conditions and participants of the artistic communicative situation. The personalised artwork representation foresees verbalised recipient's reaction. The public artwork representation is mainly actualised by the nonverbal reaction. At that, there are some peculiarities of the reaction to different kinds of arts.

An example of the verbalised reaction to the music is a personalised perception, which is followed by the appreciation of the artist's talent: Just the other day, I was invited to play my own compositions before the faculty of the Department of Music. Afterwards, Professor Jacob Mier gave me the greatest complement ever: "Richard Hall," he said, "you have a huge, flawed presence that makes your music so good that it stays on. You are, without doubt, the most edgy talent to enter my class in thirty years. " [17, p. 55]. The reaction to the music in case of the group perception foresees hands clapping, exclamations, and standing ovations of the audience, e. g., A hundred pairs of hands clapping in rhythm welcome her as she enters the lecture hall, and she finds herself submerged within a standing ovation [17, p. 237].

The pictures perception foresees a personalised perception and reaction to the artworks, actualising impressions or picture discussion, e. g., The next display is by a female painter who specializes in figurative art-fruit and vegetables super close up and in rich, glorious color. "I like those." I point to three paintings of peppers. "They remind me of you chopping vegetables in my apartment." I giggle. Christian's mouth twists as he tries and fails to hide his amusement. "I thought I managed that quite competently," he mutters. "I was just a bit slow, and anyway"-he pulls me into an embrace_"you were distracting me. Where would you put them?" "What?" Christian is nuzzling my ear. "The paintingswhere would you put them?" "Kitchen," I murmur. "Hmm. Nice idea, Mrs. Grey." I squint at the price. Five thousand euros each! "They're really expensive!" I gasp [19, p.58]. The visual artwork introduces a general description of the presented pictures according to the general stylistic of the artist's works (figurative art-fruit and vegetables super close up and in rich, glorious color). Then the communicants' attention is focused on one of these pictures. The pictures perception causes the characters' memories (They remind me of you chopping vegetables in my apartment), stimulates them to discuss some past events (I managed that; I was just a bit slow; you were distracting me), and settle issues with their price (I squint at the price. Five thousand euros each) and future location in the new house (Where would you put them?; Kitchen).

Rather often, the non-verbal reaction to the artwork is expressed by means of silence effect, which is followed by the applause and fascinated cheering, e. g., A breath of silence and wet glistening eyes. Their applause arrived like an unstoppable Tsunami. They were on their feet. They were all cheering. More. They wanted, needed, more... [17, p. 9]. The silent actions of the group recipient are expressed by word-combinations a breath of silence and wet glistening eyes. A short silence is changed by the loud reaction to the artwork, which is expressed through the comparison (applause like an unstoppable Tsunami), actions of the audience (were on their feet and were all cheering), and repetitions (More. They wanted, needed, more...).

The following extract gives an example when the silence effect is changed by ovations, compared to eruption. After that, the audience's happy and joyful emotions are described; they are caused by the musician's emerging: Yet, propelled upwards by some unseen force, their stillness erupted into lusty, lawless ovation. They were laughing and shouting and singing and dancing wildly on the tables. Welcome, Richard Hall. Welcome Amadeus Mozart. Welcome to Harvard [17, p. 9].

The comprehensive representation of the artistic communicative situation foresees the description of three stages of the artwork introduction, containing all elements of communication. The way the structure of the artistic communicative situation is presented depends on the person describing it - whether it is the narrator of the literary text, 
performer, or recipient of the artwork. Accordingly, the performer's narrations are represented by prerepresentational, representational, and postrepresentational stages. The artworks' perception in the recipient's mind is fragmented into preperceptive, perceptive, and postperceptive stages. Depending on the author's intention, the attention can be focused only on one of the stages, and other stages are realised in the shortened form or are not actualised at all.

The following artistic communicative situation is an example of the visual artwork introduction into English literary text at three stages:

I looked down, embarrassed. Then he seemed a little uneasy as well. I wasn't sure why until he hesitantly asked, "You wanna see something I did?" I nodded, and he walked me to the other side of the chamber.

There was a small intricate drawing of a forest.

"Is it in ink?"

He nodded and I looked closer. The trees were all the same or nearly identical.

There was one tree in the center that appeared to be like the others at first glance. But coursing through its roots-its veins-was a streak of red. Bright red ink.

"It's a self-portrait," I said with certainty. He looked surprised, but then not at all.

"So you're an artist, too," I added [22, p. 19]

The preintroductive stage (1) is represented by the description of the artist's feelings and the recipient's watching him. The presenter suggests going to the location where the picture is placed. The introductive stage (2) is first represented by a general description of the picture's form - size and nomination of the image (small intricate drawing of a forest). The general description is followed by the interaction between the communicants specifying the technique of the picture performance ("Is it in ink?"). After that, a more detailed description of the picture is given - it is introduced by the phrase I looked closer, and interpretation of the external form of the image (its roots-its veins). The postintroductive stage actualises the discussion of the picture, which results in the decoding and verbalising the author's intention in the recipients' minds (It's a self-portrait, So you're an artist, too).

The next example contains all elements of the artistic communicative situation: ...The Mail understands that the Prime Minister has been invited to inaugurate the newly renovated Avery Fisher Hall at New York's Lincoln Center on March 12, with a solo recital of his brilliant piano symphony Rosaline, which has caught the hearts of millions over the last few days. The US President and a host of other dignitaries are expected to honour Britain's Mozart Man in his first public performance since his early years in the smoky cafés of New York's East Village [17, p. 257]. Let us visualise the schematic structuring of the components of the communicative situation under analysis (figure 1):

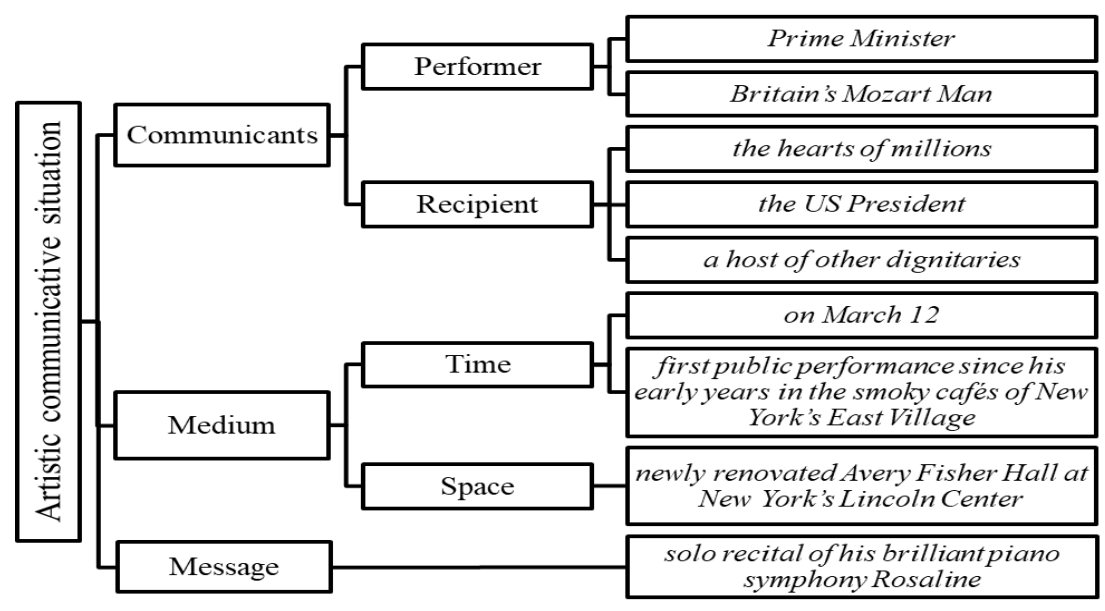

«Філологічні трактати», Том 12, № 1'2020 


\section{Figure 1. The scheme of the components structuring in the artistic communicative}

situation

The main components of the communication are gradually introduced into the artistic communicative situation - participants (presenter and recipients), medium (time and space), and message. The situation develops, and new details are explicated; they contribute to the broader reader's comprehension of the described situation.

Thus, the stages of the artworks introduction into the communicative situation are determined by complex structure and multidimensionality of the artistic phenomenon, as well as the author's intentions and peculiarities of the flow of the artistic communicative situations.

Conclusions. The artistic phenomenon is widely represented in the literary discourse. The research of the structure of the artistic communicative situation and peculiarities of its flow allowed us to differentiate preintroductive, introductive, and postintroductive stages of the artistic realia introduction. The analysis of the illustrative material gave us an opportunity to see how each stage is actualised. Accordingly, the preintroductive stage provides the readers with the time and space parameters of the communicative situation, introduces communicants, gives the description of their appearance and internal state expressed by their thoughts, emotions, and feelings. The introductive stage is marked by the occurrence of the artwork itself and foresees the description of such components as form, meaning, artwork characteristics, as well as forming of emotions caused by the artwork, verbalised in the communicants' minds or expressed by the description of the non-verbal components of communication. The postintroductive stage is accompanied by the descriptions of the impressions caused by the artwork; it is realised at the level of the verbalised and non-verbalised reaction and can stimulate the discussion of the perceived information.

The perspective of the research is implied in the further study of the communicative and discursive peculiarities of the artistic realia introduction into the literary texts. Special attention should be paid to the forms of the artworks actualisation in the communicative situations.

\section{СПИСОК ВИКОРИСТАНИХ ДЖЕРЕЛ}

1. Бацевич Ф. С. Основи комунікативної лінгвістики / Ф. С. Бацевич. - Київ : Видавничий центр «Академія», 2004. - 344 с.

2. Бехта I. А. Наратив і контекст комунікативної ситуації: стратегії інтерпретації оповідного дискурсу експериментального письма / I. А. Бехта // Дані текстових корпусів у лінгвістичних дослідженнях : монографія. - Львів : Видавництво Львівської політехніки, 2015. - С. 115-129.

3. Карасик В. И. Языковой круг: личность, концепты, дискурс / В. И. Карасик. Волгоград : Перемена, 2002. - 477 с.

4. Манакін В. М. Мова і міжкультурна комунікація / В. М. Манакін. - К. : ВЦ «Академія», 2012. - 288 с.

5. Плеханова Т. Ф. Дискурс-анализ текста / Т. Ф. Плеханова. - Минск : ТетраСистемс, 2011. - 368 с.

6. Прохоров В. Ф. Лингвистическое осмысление эмоциональных состояний / В. Ф. Прохоров // Нова філологія : збірник наукових праць. - Запоріжжя : ЗНУ, 2013. C. $120-123$.

7. Рудик I. М. Культурна специфіка невербального коду в міжкультурній комунікації / I. М. Рудик // Вісник Житомирського державного університету імені Івана Франка. - Житомир : ЖДУ імені Івана Франка, 2005. - Вип. 23. - С. 102 103.

8. Солощук Л. В. Вербальні і невербальні компоненти комунікації в англомовному дискурсі : монографія / Л. В. Солощук. - Харків : Константа, 2006. - 300 с. 
9. Суродейкіна Т. В. Лінгвокогнітивні та дискурсивні характеристики англомовної мистецтвознавчої термінології : автореф. дис. на здобуття наук. ступеня канд. філол. наук : 10.02.04 / Т. В. Суродейкіна. - Чернівці, 2008. - 20 с.

10. Черник М. В. Номінативно-стилістичні та комунікативно-дискурсивні параметри актуалізації феномену мистецтва (на матеріалі англомовних художніх текстів) : дис. ... канд. філол. наук : 10.02.04 / Черник Марина Володимирівна ; Запоріз. нац. ун-т. - Запоріжжя, 2018. - 246 с.

11. Hausman C. R. A Discourse on Novelty and Creation / C. R. Hausman. - SUNY Press, 2012. $-171 \mathrm{p}$

12. Kulish V. S. Verbal and Non-Verbal Component of Emotiveness in Political Discourse: Translation Aspect / V.S. Kulish, Ya.M. Niemtseva // Філологічні трактати. - 2018. T.10, № 4. - C. 37-43.

13. Ludden D. Is Music a Universal Language? Expressing the shared human experience [Electronic resource] / D. Ludden // Psychology Today. - 2015. - Mode of access : https://www.psychologytoday.com/blog/talking-apes/201507/is-music-universallanguage.

14. Rippl G. Handbook of Intermediality: Literature - Image - Sound - Music / G. Rippl. Walter de Gruyter GmbH \& Co KG, 2015. - 701 p.

\section{СПИСОК ДЖЕРЕЛ ІЛЮСТРАТИВНОГО МАТЕРІАЛУ}

15. Cooper J. Pandora / J. Cooper. - Corgi Books, 2003. - 752 p.

16. Draanen Van W. Flipped / W. Van Draanen. - New York : Alfred A. Knopf, 2001. $156 \mathrm{p}$.

17. Elking M. Executing Mozart [Electronic resource] / M. Elking. - Mode of access : http://executingmozart.com/.

18. James E. L. Fifty Shades Darker / E. L. James. - Vintage Books, 2011. - 373 p.

19. James E. L. Fifty Shades Freed / E. L. James. - Vintage Books, 2012. - 579 p.

20. James E. L. Fifty Shades of Grey / E. L. James. - Vintage Books, 2011. - 356 p.

21. James E. L. Grey / E. L. James. - Vintage Books, 2015. - 576 p.

22. Talkington A. Liv, forever / A. Talkington. - New York : Soho Teen, 2014. - 132 p.

\section{REFERENCES}

1. Batsevych F. S. Fundamentals of the communicative linguistics. Kyiv : Vydavnychyi tsentr "Akademiia", 2004. 344 p.

2. Bekhta I. A. Narration and context of the communicative situation: strategies of the experimental writing narrative discourse interpretation. Data of the textual corps in linguistic research : monograph. Lviv : Vydavnytstvo Lvivskoyi politekhnyky, 2015. P. 115-129.

3. Karasyk V. I. Language circle: personality, concepts, discourse. - Volhograd: Peremena, 2002. 477 p.

4. Manakin V. M. Language and intercultural communication. K. : Vydavnychyi tsentr "Akademiia", 2012. 288 p.

5. Plekhanova T. F. Discourse-analysis text. Minsk : TetraSistems, 2011. 368 p.

6. Prokhorov V. F. Linguistic comprehension of emotional states. Nova filolohiia : collection of scientific works. - Zaporizhzhia : ZNU, 2013. - P. 120-123.

7. Rudyk I. M. Cultural specifics of non-verbal code in intercultural communication. Visnyk of Ivan Franko Zhytomyr State University. Zhytomyr : Ivan Franko Zhytomyr State University, 2005. Iss. 23. P. 102-103.

8. Soloshchuk L. V. Verbal and non-verbal components of communication in English discourse: monograph. Kharkiv : Konstanta, 2006. 300 p.

9. Surodeikina T. V. Linguocognitive and discoursive characteristics of English artistic terminology: thesis for Candidate in Philology : 10.02.04. Chernivtsi, 2008. 20 p. 
10. Chernyk M. V. Nominative, stylistic, communicative and discursive parameters of art phenomenon actualisation (based on English literary texts): Dissertation ... Candidate in Philology : 10.02.04. Zaporizhzhia National University, Zaporizhzhia, 2018. 246 p.

11. Hausman C. R. A Discourse on Novelty and Creation. SUNY Press, 2012. 171 p.

12. Kulish V. S., Niemtseva Ya.M. Verbal and Non-Verbal Component of Emotiveness in Political Discourse: Translation Aspect. Filolohichni traktaty. 2018. Vol.10, № 4. P. 37-43.

13. Ludden D. Is Music a Universal Language? Expressing the shared human experience [Electronic resource]. Psychology Today. 2015. Mode of access : https://www.psychologytoday.com/blog/talking-apes/201507/is-music-universallanguage.

14. Rippl G. Handbook of Intermediality: Literature - Image - Sound - Music. - Walter de Gruyter GmbH \& Co KG, 2015. 701 p.

\section{LIST OF ILLUSTRATIVE MATERIAL}

15. Cooper J. Pandora. Corgi Books, 2003. 752 p.

16. Draanen Van W. Flipped. New York : Alfred A. Knopf, 2001. 156 p.

17. Elking M. Executing Mozart [Electronic resource]. Mode of access : http://executingmozart.com/.

18. James E. L. Fifty Shades Darker. Vintage Books, 2011. 373 p.

19. James E. L. Fifty Shades Freed. Vintage Books, 2012. 579 p.

20. James E. L. Fifty Shades of Grey. Vintage Books, 2011. 356 p.

21. James E. L. Grey. Vintage Books, 2015. 576 p.

22. Talkington A. Liv, forever. New York : Soho Teen, 2014. 132 p.

Received: 25 December, 2019 